\title{
Global capital and media communication ownership in New Zealand
}

\section{ABSTRACII}

This article identifies recent developments in the ownership and management of New Zealand media institutions since Bill Rosenberg's 2009 article in Pacific Journalism Review. New Zealand is enmeshed within global capitalism; a reality which shapes contemporary ownership patterns. Often the media ownership discussion in New Zealand is centred on media moguls, but they are answerable to their investors, shareholders, international investment banks, fund managers and venture capitalists whose primary objective is to maximise profit rates. New Zealand media corporations treat news as a commodity and news organisations as revenue generators. Consequently, public media space is shrinking as the practice of journalism declines.

Keywords: Media ownership, convergence, global capitalism, financial institutions, concentration

\section{MERJA MYLLYLAHTI and WAYNE HOPE AUT University, Auckland}

7 HE OWNERSHIP structure of New Zealand's news media is not dramatically different to that in 2008 when Rosenberg delivered his

last media ownership report (Rosenberg, 2008). As he observed three years ago:

four companies, all overseas owned, dominate the New Zealand news media. There is a near duopoly in two of the three main media-print and radio - a monopoly in pay television, and only three significant competitors in free-to-air television including the state-owned channels. (Rosenberg, 2008) 
In 2009, Rosenberg noted that his earlier observation was still valid:

It is remarkable that ownership of the media has remained largely stable during the year. This is as much a result of the credit crunch as despite it: one of the major owners tried to sell and failed. The ownership continues to be highly concentrated with further acquisitions and centralisation by the major owners. (Rosenberg, 2009, p. 186)

Since then one noticeable change in New Zealand's broader communication structure is Telecom NZ's decision to pull out of Yahoo!Xtra. In April 2011, Telecom NZ announced (2011) that it was selling its stake in the company after four years to majority owner Yahoo7. After the sale, the Yahoo!Xtra business was rebranded to Yahoo!New Zealand-somewhat of a misnomer since the company is owned by the American Yahoo and Australia's Seven Network.

In 2011, there are still four major players in the New Zealand media market: APN News \& Media, Fairfax Media, MediaWorks and News Corporation/ Sky. New Zealand news media is dominated by overseas companies and these companies are primarily owned by international financial institutions and a handful of foreign media moguls: Australian/American Rupert Murdoch (News Corporation), Irish Tony O'Reilly (Independent News \& Media) and Australian mining billionaire Gina Rinehart, who in 2010 bought an AUD\$50 million stake in Fairfax Media, equivalent to 1.5 percent of the company's stock at the time (Lee \& Kruger, 2010). Fairfax's chairman Roger Corbett commented on the share purchase: 'The company welcomes the interest, investment and show of confidence from all our shareholders.' (Lee \& Kruger, 2010). Under the stock market rules Rinehart does not need to flag her ownership unless it exceeds five percent of company's shares.

The biggest shareholder of APN News \& Media is Irish Independent News \& Media (INM) which owns 31.6 percent of the company's shares (APN, 2011). In 2009, the Irish owner tried to sell its majority stake in APN, but failed to do so (INM can't find buyer for its APN stake, 2009). In June 2011, APN's owner hit the headlines after a 'dramatic' annual general meeting in Ireland (O'Carroll, 2011). According to media reports (O'Carroll, 2011), Denis O'Brien, who is a majority shareholder of INM and the company's CEO, Gavin O'Reilly (the son of Sir Tony O'Reilly), had a public 'war of words' after O'Brien's nominee was removed from the INM board (O'Carroll, 2011). 
As O'Carroll remarked, 'the peace that existed between the two camps over the past two years is well and truly over'. After the public arm wrestling, the Irish press speculated that O'Brien was getting ready to make a full takeover bid of INM which had seen its value badly damaged after the global financial crisis. In early 2007, the company had a market valued at 2.4 billion euros, but in June 2011 it was just over 310 million euros (Split down the middle at INM, 2011).

The following tables (1, 2, 3 and 4) reveal the major ownership stakes within Fairfax Media and APN Media and Sky TV NZ. Any owner of 5 percent or more of the company's shares is required to disclose this information to the stock exchanges. Nominee shareholders are normally companies which hold shares for a group or groups of shareholders.

Table 1: Ownership of Fairfax media
\begin{tabular}{|l|c|}
\hline National Nominees Ltd & $18.75 \%$ \\
\hline JP Morgan Nominees Australia Ltd & $16.75 \%$ \\
\hline Marinya Media Pty Ltd & $9.68 \%$ \\
\hline HSBC Custody Nominees & $8.81 \%$ \\
\hline Citicorp Nominees Pty Ltd & $6.08 \%$ \\
\hline & $\begin{array}{c}\text { (5\% or more of the total } \\
\text { number of shares) }\end{array}$ \\
\hline Substantial owners & \\
\hline Marinya Media & \\
\hline National Australia Bank & \\
\hline Commonwealth Bank of Australia & \\
\hline Maple-Brown Abbott Ltd & \\
\hline
\end{tabular}

Source: Fairfax Media (2010). Annual Report

\begin{tabular}{|l|l|}
\hline Table 2: Ownership of APN media \\
\hline Independent News \& Media Australia & $21.7 \%$ \\
\hline News \& Media & $9.9 \%$ \\
\hline Orbis Investment Management & $8.4 \%$ \\
\hline Perpetual Investments & $8.3 \%$ \\
\hline MLC Investment Management & $5.9 \%$ \\
\hline Paradice Investment Management & $5.9 \%$ \\
\hline Maple-Brown Abbott & $4.9 \%$ \\
\hline
\end{tabular}

Source: APN (2011a). Major shareholders.

190 PACIFIC JOURNALISM REVIEW 17 (2) 2011 


\begin{tabular}{|l|c|}
\hline Table 3: Ownership of MediaWorks \\
\hline Ironbridge Capital & Around $87 \%$ \\
\hline Goldman Sachs JB Were & Not disclosed \\
\hline ABN Amro & Not disclosed \\
\hline Royal Bank of Scotland & Not disclosed \\
\hline BOS International & Not disclosed \\
\hline
\end{tabular}

Source: MediaWorks, Vaughn, G. 2010.

\section{Table 4: Ownership of Sky TV NZ}

\begin{tabular}{|l|l|}
\hline Nationwide News Pty Ltd & $43.65 \%$ \\
\hline Todd Communications Ltd & $11.11 \%$ \\
\hline Commonwealth Bank of Australia and subsidiaries & $4.43 \%$ \\
\hline AXA Asia Pacific Holdings Ltd & $5.15 \%$ \\
\hline ABN Amro Asset Management & $5.11 \%$ \\
\hline
\end{tabular}

Source: Sky TV NZ, 2011a.

The media ownership discussion in New Zealand is often centred on media moguls, but it is increasingly important to realise that the moguls are accountable to their investors, shareholders, international investment banks, funds and venture capitalists whose primary objective is to maximize their return. As Dwyer points out, financial institutions and, especially private equity firms, show an increasing interest in media companies $(2010$, p. 6263). These institutions are not bound by the same disclosure rules as stock market listed companies and, as a result, are not required to be as open and transparent. According to Winseck, banks, equity and other financial firms are no longer simply backers of media companies; they also have 'positions on the boards of directors at media companies' (2008, p. 40).

Does ownership matter then? According to a worldwide poll by the BBC World Service (2007), 59 percent of those surveyed regard media ownership as a major issue because the owner's political views are often aired in their news media and news stories. As Doyle puts it:

.. one of the main concerns surrounding concentrations of media ownership is the risk for democracy and to the wider political system when individual voices gain excessive control over the media. Democracy is threatened if individual media owners, with the power to propagate a single political viewpoint, are allowed to predominate over the supply of media. (Doyle 2002, p. 171- 172) 
There are some signs that media ownership matters to New Zealanders as well. In May 2011, the 'Save TVNZ7' site on Facebook had 1,683 people 'liking' it and 'Save NZPA' had 180 supporters on this social networking site. The founder of the 'Save TVNZ7'- group, Myles Thomas, claimed that the government's decision to close down the TV channel would reduce New Zealand's public broadcasting to Third World levels (Abandonment of public service TV 'tragic' for New Zealand, 2011).

Next year there will be no such thing as public service TV in New Zealand. Not only does that put us behind the rest of the developed world, it also puts us behind much of the third world. Every other developed nation can provide it - even Estonia, and many third world countries. (Abandonment of public service TV 'tragic' for New Zealand, 2011).

Drinnan claims New Zealand government is making decisions with media companies behind the scenes and without any input from the New Zealand public (2011a):

The issue is not so much about whether this Government is making bad decisions. It is that it is making decisions in secret with industry players that help some commercial interests over others. (Drinnan, 2011a, p. 7).

\section{Recent developments within the New Zealand media landscape}

\section{NZPA: End of a 130 year old institution}

Shock waves went through the New Zealand media sector in April 2011 when Fairfax and APN, the biggest shareholders of the New Zealand Press Association (NZPA), told that they were pulling out. The doors of the news agency close in August 2011 with the loss of 40 jobs of reporters, sub-editors and editors. For 130 years NZPA has provided tailored news services to New Zealand's media markets. It was founded in 1880 as the United Press Association, but adopted its present name in 1942. The Engineering, Printing and Manufacturing Union (EPMU) described the closure as a 'huge loss for news journalism in New Zealand' (NZPA, 2011a). As the EPMU national industrial officer Paul Tolich commented:

A national news agency is an essential part of a healthy democracy... The loss of so many journalistic positions means there will be less news 
gathering and researching in New Zealand... This represents a decline in diversity in New Zealand's news media. ("NZPA closure a huge loss for news journalism - union,” 2011).

Kiwiblog raised particular concerns about the proposed NZPA closure. 'I think the decision is a disaster for parliamentary reporting, and bad for the overall news industry. NZPA are the one news agency in parliament that covers every bill before the House.' ('Fairfax kills NZPA,' 2011). The agency's other perceived strength was 24 hours news coverage with a non-commercial focus: 'The other agencies naturally focus on stories which sell-which will make for good television, can run on a front page etc. But NZPA are not about 'sexy" stories.' (Fairfax kills NZPA, 2011). NZPA is 60 percent owned by the Australian Fairfax Media and 40 percent by the Australian APN. Fairfax Media's Chief Executive Allen Williams justified the withdrawal by emphasizing Fairfax's investment in its own live news services (News agency under review, 2011). He also argued that the NZPA was not providing the content required by Fairfax:

News should not be treated as a commodity - media companies can and should establish points of difference with their coverage... Fairfax has made a choice to concentrate on development of its own unique content rather than subscribing for non-exclusive content from NZPA. (News agency under review, 2011)

APN has publicly stated that it was keen to keep NZPA going, but could not do it without Fairfax's backing. The Radio New Zealand quoted APN's CEO Rick Neville as saying: 'We've been working quite hard around the board table for many, many months to try to persuade Fairfax that the NZPA model is a good one and should be supported. But it was becoming more and more apparent that Fairfax was expanding its own content resources.'(Media giant says it wanted to save NZPA, 2011). NZ Scoop claimed the board of NZPA asked the news agency to stop selling some of its news services to all clients, which led to the poorer financial situation and agencies increased reliance of Fairfax and APN (NZ: Probable NZPA closure sends media shockwaves, 2011). Scoop warned that the closure of the national news agency would threaten news coverage and democracy: 
The biggest risk to the national news discourse - and the democratic process - of NZPA closing down will be that readers will be dependent on news sources that are not truly national. Both Fairfax and APN have blind spots in their national coverage, provincial regions where they don't own newspapers to feed into their internal news networks. (NZ: Probable NZPA closure sends media shockwaves, 2011)

Interestingly APN and Fairfax are now in a process of building their own news services. APN is developing its own news agency to be called APNZ, and Fairfax is creating separate national news services (Drinnan, 2011b). If this is the case, it seems fair to state that the New Zealand news media is being further absorbed by APN and Fairfax Media.

\section{MediaWorks: Government backs the venture capitalist owner}

MediaWorks is a New Zealand based media company which owns television, radio and interactive media outlets such as TV3 and FOUR and ten radio networks, including RadioLive, The Rock and Kiwi FM. It is owned by a foreign venture capital firm and other financial institutions. The Australian private equity group, Ironbridge Capital, gained full control of MediaWorks in 2007, after which the company was delisted from the New Zealand Stock Exchange, NZX (MediaWorks, 2011a).

In June 2011, chief of the MediaWorks television, Jason Paris, resigned after a year in the position-a move that surprised the media and the markets. Quoting unnamed sources, Bond and Nippert (2011) claimed that there was a rift between Paris and Ironbridge Capital over the funding for programming. Outsiders commenting on the departure claimed that Paris has lost confidence in the company, because there was no money for programming (Bond \& Nippert, 2011). In 2009, MediaWorks was heavily indebted and forced to recapitalise. After getting $\$ 70$ million of new capital, new investors stepped into MediaWorks: Goldman Sachs JBWere took a 12.9 percent stake in the company as a part of the new arrangement (Vaughan, 2010). After restructuring MediaWorks' debts, its chairman, Brent Harman, stated that the media company was in good shape financially:

The recapitalisation, combined with the restructure of the company's banking arrangements, has placed the company on a sound financial footing. This, together with the improving ad market conditions, places the company in an excellent position for 2010 and beyond. (Ironbridge Capital, 2009) 
In light of this comment, it was not surprising that the New Zealand government was criticised for deferring the \$43million debt MediaWorks owed for its radio licences after 'some serious lobbying' from the media company (Govt lends MediaWorks \$43m against advice, 2011). Critics attacked the government's decision mainly because MediaWorks is principally owned by a venture capital company. Media commentators and politicians have found it hard to understand why the New Zealand government was assisting MediaWorks' venture capital owner. Labour party's MP Trevor Mallard voiced displeasure on his blog:

At a time when many Kiwi companies are struggling, taxpayers will want to know why a private company was given a $\$ 42$ million low interest deferred payment scheme for radio licensing agreement, and so far ICT Minister Steven Joyce has failed to provide any reasonable answers to that question. (Mallard, 2011)

New Zealand First's leader Winston Peters called on the government to explain why it was using taxpayer's money to back a privately and foreignowned enterprise.

The government is running around telling New Zealanders how public expenditure has to be slashed while at the same time it is bailing out its mates in the media industry...There seems to be a different set of standards for private enterprise under this government. We are sure there are far more worthy causes to support in New Zealand at present. (Winston calls on govt to explain 'bail-out' of MediaWorks, owned by Johnny Foreigner, 2011).

Prime Minister John Key defended the government's decision to use taxpayer's money to help MediaWorks and insisted that the government's loan scheme was tailored to help the whole radio industry, not just MediaWorks. 'Frankly I'd rather see people paying over a longer period of time if it means they stay in business.' (Prime Minister defends loan to MediaWorks, 2011). The Prime Minister first publicly denied that he had talked with MediaWorks or its representatives-including MediaWorks former head Brent Impeyabout the deferred payments, but later admitted that: 'In early August 2009 I ran into Brent Impey at a social event in Auckland where he briefly raised the issue with me. I passed his comments on to the responsible minister.' (Key, 2011) 
The government insists that MediaWorks is not the only beneficiary of deferred payment. In his answer to a parliamentary question, the Minister of Communications and Information Technology, Steven Joyce, revealed that the government had decided, in October 2009, to offer all New Zealand radio broadcasters deferred payment terms on their spectrum licence renewals (2011). The deal allowed radio companies to pay 20 -year leases to frequencies in five installments rather than in one lump sum. It is interesting to note that Joyce was the founder and owner of Radio Works for 18 years before the company was bought out by Can West and became MediaWorks (Kedgley, 2011a). In his answer to a parliamentary question, Joyce insisted that the government was not bailing out MediaWorks (Joyce, 2011) since the company was paying 11.2 percent interest on its loan.

All I can say is that it is a deferred payment for frequencies, and the
member needs to understand that. I point out too that, ultimately, if the
Government had not offered it and radio broadcasters had gone broke,
then the member and his friends would have been accusing us in the
House of not doing anything to help save jobs in the broadcasting
industry. (Joyce, 2011)

Keown claims that Joyce first rejected the loan proposal after receiving advice from economic development officials, but that MediaWorks then asked the cabinet to push the decision through to help the company recapitalise (2011). Cabinet looked at the proposal in early October 2009, and after further representations were made to the Prime Minister John Key, the Broadcasting Minister Jonathan Coleman and the Economic Development Minister Gerry Brownlee, after which it was decided to support MediaWorks and other radio stations. It appears that the government's payment to MediaWorks was against the advice received from the Treasury and the Ministry of Economic Development. Documents released under the Official Information Act reveal that the Treasury was against the government decision because it feared that the other licence holders might request similar treatment (Keown, 2011). Treasury noted that based on the modelling by Deloitte, the radio licence prices for MediaWorks and TRN were affordable and were not unlikely to undermine network viability.

It should be noted that MediaWorks is not the only broadcaster who has benefitted from the government's initiative: Overall nine broadcasters have 
made use of the deferred payment scheme since it was introduced in October 2009. The scheme allows broadcasters to pay their licences over a period starting 2011 and finishing in year 2031 (MediaWorks whacked with 11.2\% interest on deferred payments to govt, 2011).

The significance of this episode concerns the relationship between the New Zealand government, a privately owned company and its venture capitalist investors. As Drinnan points out, the loan deal between the MediaWorks and the government gives the latter unusual powers over the company (2011c). If the owners of MediaWorks decide to sell the company, the government can decide if the agreed loan arrangement is passable to the new owner. If the company's ownership structure changes without government's approval, the media company would default on the loan and be obliged to pay the outstanding balance. If it failed to do so the government would be able to take back the frequencies. This could mean government ownership (at least for a short period of time) for networks such as RadioLive, More FM, The Edge, The Rock, Solid Gold and The Breeze.

After recapitalisation and deferred payments, MediaWorks indicated in 2011 that it was financially in a sound financial state and in no need of government money. In March 2011, the company published a press release with the heading 'Statement on a misleading NZ Herald article re MediaWorks.' (MediaWorks, 2011b). In the press release, signed by Ironbridge Capital's operating partner Kerry McIntosh and partner Mike Hill, the company states:

... the financial position of the company is good, earnings have improved and debt has been reduced... MediaWorks generated earnings before interest and tax and depreciation (EBITDA) of \$50.1 million in FY10. That represented an increase of 11 per cent. We consider this to be a credible result in a tough market and compares favorably with our peers. (MediaWorks, 2011b)

Closing down TVNZ7: The role of the state broadcaster is to make money Publicly owned and managed television companies are under cost-cutting pressure. In Britain, the British Broadcasting Corporation (BBC) is considering closing down its $\mathrm{BBC} 3$ and $\mathrm{BBC} 4$ channels and has already restructured its radio services. The BBC Trust chairman, Sir Michael Lyons, warned in January 2011 that the corporation had to find $£ 300$ million of savings after changes to its licence fee policies (Plunkett, 2011). In New Zealand, the 
government has put an axe to the public service channel TVNZ7 after three years of operation. Funding will end in June 2012 with the loss of 20-30 fulltime positions. After this dateTVNZ7 can apply for the NZ on Air funding if it wants to continue broadcasting its programmes, such as Media 7 and Talk Talk (Cheng, 2011), but will have to compete with other broadcasters, including commercially run TV3, Prime and Sky TV. NZ on Air is a government broadcast funding agency which invests in local TV, radio and new media content.

TVNZ7 was launched in March 2008 as a commercial-free digital channel and with 24-hour news and information coverage. This is currently available via Freeview and Sky platforms. The channel's annual running cost is $\$ 15$ million (Cheng, 2011). The New Zealand government spends around \$231 million a year on all forms of broadcasting, including Māori Broadcasting, Radio New Zealand, community radio and television stations, Freeview and NZ on Air (which received about $\$ 81$ million last year) (Watkins, 2011).

In a statement confirming the closure of TVNZ7, the chief executive of TVNZ, Rick Ellis, stated that TVNZ7 has been 'providing New Zealanders with unique perspectives on the issues of today in ways that we cannot otherwise provide through our core channels of TV ONE and TV2.' ("TVNZ7 to close as govt confirms no more funding”, 2011). The Broadcasting Minister, Jonathan Coleman, said that the government would continue its support for New Zealand based programming through the NZ on Air. While defending government's decision he commented:

Sinking money into a public broadcasting infrastructure which continues to suck up money in the long-term doesn't make sense ... It's important to fund the content, not some monolithic public broadcaster. (TVNZ7 to close as govt confirms no more funding, 2011).

In response, Peter Thompson (2011) criticised the government for having double standards on broadcasting policy. He referred to the fact that the government has been involved in funding privately owned MediaWorks, as it announced a funding withdrawal from commercial-free public service television. He also stated that the National-led government has a 'less sympathetic approach' to public broadcasting. 'The government's failure to continue funding for TVNZ7 is underpinned by a long history of tensions between ministerial policy priorities, with details often misrepresented by politicians and news media' (Thompson, 2011).

198 PACIFIC JOURNALISM REVIEW 17 (2) 2011 
In April 2011, a group of 60 New Zealand academics wrote an open letter to the government in which they opposed the closing of TVNZ7 and TVNZ6, and expressed concern about the government's intention to 'dismantle the little that is left of public broadcasting in our country' in New Zealand (Open letter on NZ public broadcasting policy, 2011). The letter warned government against relying on Sky to fill the gap left in programming after the closure of TVNZ7. It observed that public service television was crucial to a small country like New Zealand because commercial channels could not provide a whole range of programmes 'that viewers want and should be able to access in the interests of democracy as well as cultural identity'.

Pay television cannot satisfy the same needs. It would be wrong to assume that Sky provides a range of programming that can replace the role of a public service channel. Sky provides relatively little in the way of local content other than sports, Sky having effectively monopolised the rights to the latter. (Open letter on NZ public broadcasting policy, 2011.).

The signatories pointed out that TVNZ7 and TVNZ6 had provided the public with content which the commercial channels could not provide. For example, TVNZ7 and TVNZ6 had produced local, advertising free, high quality programs for children as well as in-depth news and current affairs programmes. The government was urged to reconsider its funding withdrawal from TVNZ7 and to reassess broadcasting policy priorities. The fate of TVNZ7 and broader broadcasting policy was debated in the New Zealand Parliament in May 2011 as politicians pondered imminent changes to be made for the TVNZ Amendment Bill. The bill will replace the current TVNZ Charter and will give the company powers to determine its own priorities. Anticipating changes to TVNZ's mandate, Forsyth Barr analyst Rob Mercer commented that 'the new TVNZ, under National's leadership, will have a clear mandate to re-establish profit as its primary objective and for the senseless taxpayerfunded projects to be axed' (Keall, 2011). On the other hand, the Green Party MP Sue Kedgley described the bill as 'shocking'(Kedgley, 2011b).

It will turn TVNZ into a nakedly commercial broadcaster that is focused solely on chasing ratings and advertising revenues and is indistinguishable from any other commercial broadcaster. Once this bill is passed, TVNZ will exist for the sole purpose of returning a dividend to the government, and it will not be expected to deliver anything other than a profit to the government. (Kedgley, 2011b) 
Coleman, in his response to the parliamentary questions, pointed out that TVNZ was a state-owned enterprise with more than 90 percent of its income already coming from commercial revenue. Yet at the same time he admitted that TVNZ had not been able to keep its obligations to its main shareholder-the government.

TVNZ has struggled to return a consistent dividend to the government. This has been due, in part, to the uncertainty created by the government's long-term expectations of it. Removing the charter is being honest and not trying to pretend that TVNZ is something that it plainly is not. (Coleman, 2011)

Coleman gave assurances that TVNZ would continue to provide relevant, local content to the New Zealand public. However, he also said:

TVNZ will have the flexibility it needs to effectively pursue commercial objectives and to continue its transition from a traditional broadcaster to a multiplatform digital media company with diverse income-streams and services. (Coleman, 2011)

The New Zealand government wants to save taxpayers' money, but the decision to close down the TVNZ7 and the TVNZ6 is beneficial for one operator: Sky TV and its shareholders. Rob Mercer, an analyst at Forsyth Barr, regards the news of the TVNZ7 closure as good news for the long term success of the pay TV (Keall, 2011). Evidence to support Mercer's argument is mounting. In March 2011, Sky TV New Zealand announced that TVNZ was launching a 24 hour Kidzone channel on the Sky platform (Sky TV NZ, 2011b). The popular pre-school children's Kidzone- programme is publicly available on TVNZ7 until next 2012, but already the new TVNZ Kidzone24 is 'available as part of the SKY Basic Digital Package'. (Sky TV NZ, 2011b). The TVNZ chief executive, Rick Ellis, commented on the partnership deal:

Kidzone has been an increasingly popular block of programming, providing educational and entertaining content for young New Zealanders, with a significant amount of locally produced programming. It is fantastic that we are now able to offer a commercially-viable, expanded Kidzone channel, on the SKY platform. (Sky TV NZ, 2011b)

The TVNZ7's sister channel, TVNZ6, has now been discontinued and replaced with U, described by TVNZ as 'a ground-breaking new channel 
which integrates online social networking with broadcast content for the first time on New Zealand screens.' In general, U is said to be a 'commercial, free-to-air digital channel which features a mix of real life and factual entertainment programming and is aimed at all Kiwis aged 15-24.' (TVNZ, 2011) $\mathrm{U}$ is broadcast on Freeview and Sky TV and as a commercial channel, its main purpose is to sell advertisements and attract young audience.

Fairfax and APN: Chopping, closing, selling, outsourcing, converging There is clear pressure on New Zealand's leading media companies, Fairfax Media and APN News \& Media, to cut costs, close down their non-profitable businesses, sell non-core assets, outsource expensive work and reduce their overall workforce. Both companies warned in May 2011 that a drop in advertising income was hitting their profits. The advertising revenues of printed newspapers were also falling overseas. In the first quarter of 2011 the advertising revenue for US newspapers was the lowest in 27 years. According to The Huffington Post, the weak economy and a shift by advertisers to internet based outlets had damaged US newspapers revenue streams (Newspaper ad revenue falls to lowest level in 27 Years, 2011).

In June 2010, Fairfax Media had already decided to close down The Independent - the Auckland-based business newspaper-after 20 years of existence. The eight journalists working for the paper were transferred to work on the company's Businessday brand. In a press release entitled 'Best in the business at business', the company said that the announcement meant 'further strengthening the business journalism in both its daily newspapers and online through Businessday.co.nz' (Fairfax, 2010). Fairfax Group executive editor Paul Thompson argued in a press release that the move strengthened the media company's business coverage to the larger audience online. Thompson stated: 'We believe it is particularly important to provide stronger business coverage online as that is where most readers of business news go first for reliable and agenda-setting stories.' (Fairfax, 2010)

The closure of The Independent made only a few headlines, but Fairfax Media has since been in the media spotlight for other reasons. In April 2011, the company confirmed that it was withdrawing from the NZPA, and just a month later it appointed John Crowley as the editor of Fairfax New Zealand News to oversee its 'journalism development' as the company started to plan ahead before NZPA's closure in August 2011 (Fairfax appoints NZ news head, 2011). In a separate appointment, Timaru Herald editor David King was named 
as general manager for editorial services. Fairfax Media NZ chief executive Allen Williams said the appointments reflected the company's commitment to delivering high quality news:

Our priority is to invest in our respected, independent journalism. As
part of his new role, John Crowley is recruiting new reporters and
editors who will significantly strengthen our editorial ranks. We are
also focused on improving the effectiveness of the staff who produce
our newspapers and websites. (Fairfax appoints NZ news head, 2011).

Fairfax's publishing portfolio in New Zealand includes metropolitan newspapers The Dominion Post, The Press and The Waikato Times; Sunday papers Sunday News and Sunday Star-Times; magazines such as NZ Life \& Leisure and NZ House \& Garden as well as online news site stuff.co.nz. In a press release, published February 2011, the company claimed that its media brands reached 85 percent of New Zealand's population aged over 15 years (Fairfax, 2011a). The press release reads: 'CEO of Fairfax Media, Allen Williams, said that the positive results reflect the significant on-going investment into quality journalism and a "content first, channel second" approach.' In its press release, released also in February 2011, APN went on to claim that its brand portfolio gives the 'company unrivalled reach into the important Auckland market' (APN, 2011b). According to the press release, 80 percent of Aucklanders connected at least once a week with at least one of its brands. The press released also said: 'APN is hitting the ground running in 2011 with strong results in both readership and circulation for its portfolio of newspaper, online and magazine brands.' APN claimed that more than two million New Zealanders were reading its newspapers 'on a typical day' (APN, 2011c). APN is the publisher of the NZ Herald and Sunday title Herald on Sunday, online news site nzherald.co.nz, ten regional newspapers and magazines such as Woman's Weekly and NZ Magazines. It also owns The Radio Network in New Zealand.

Despite their positive readership statements, both Fairfax Media and APN claimed later that their profits were partly hit by the Christchurch earthquakes, Queensland floods and the strong Australian dollar which hurt their New Zealand earnings (BusinessDesk, 2011). The squeeze on each company's revenues has forced both groups to cut costs. In a trading statement, Fairfax CEO Greg Hywood said that the 'revenue declines have been experienced 
in Australian metropolitan and NZ publishing businesses' (Fairfax, 2011b). In the same trading statement, he promised that despite the cost cutting the company would invest in journalism:

Fairfax will be investing in more high calibre reporters and writers, an expanded trainee program and multi-media training and equipment. Quality journalism and content will be key to maintaining and developing new markets and audiences. (Fairfax, 2011).

A few weeks after this statement, it was reported that Fairfax was planning 100 redundancies in its New Zealand operations and a further 160 in Australia, including regional pre-press centers and national printing, distribution and advertising operations (Jackson \& Sinclair, 2011). On May 12, 2011, Hywood confirmed in a staff email that Fairfax was outsourcing its Melbourne and Sydney based subediting production to Pagemasters with 82 job losses (Chessell, 2011).

In May 2011, Fairfax Media also decided to sell its radio assets in Australia to pay down debt and increase corporate flexibility (Fairfax to sell radio stations, 2011). The stations for sale included metropolitan newstalk stations: Sydney (2UE), Melbourne (3AW), Brisbane (4BC) and Perth (6PR), and three metropolitan music stations in Melbourne, Brisbane and Perth along with nine regional radio licences in Queensland and South Australia. For Fairfax's CEO, Greg Hywood, the sale reflected strong demand for the assets at a time that required a 'review of opportunities to maximise shareholder value and the mix of assets we own.' (Fairfax to sell radio stations, 2011). According to Ahmed there has been strong demand for Fairfax's radio assets from private equity groups, particularly Archer Capital and Ironbridge Capital-which owns MediaWorks - as well as from Murdoch's private investment company Illyria (2011).

Although, Fairfax and APN are fierce competitors in a cost cutting environment, they are also exploring ways to converge their operations. According to Chessell and Ahmed the companies are seeking to combine their New Zealand printing operations, where they mutually dominate the newspaper market (2011). The two companies have not officially confirmed this, but APN chief executive, Brett Chenoweth, has confirmed that the company is looking for a lighter business model: 'The industry is changing. In a digital world it makes sense for media companies to look at infrastructure-light business models. 
We need to focus on content, editorial, sales and marketing through a range of different platforms.' (Chessell \& Ahmed, 2011).

APN News \& Media had already begun streamlining its New Zealand printing operations in 2010. In that year it announced the closure of its Manukau printing plant with the loss of 150 jobs (APN to close printing plant, 150 jobs lost, 2010). The company admitted then that its New Zealand gloss printing operations were no longer core to its business strategy. APN has also announced that it was planning to restructure after earnings for the first half of 2011 were substantially less than in the previous year. The company's chairman, Gavin O'Reilly, told investors at their annual general meeting that APN would implement 'a round of restructuring initiatives' in response to the earnings fall (APN to restructure as earnings slashed, 2011). At the time of writing this article, the company had not publicly announced what kind of restructuring policies it would implement. In his presentation at the APN News \& Media annual meeting the CEO, Brett Chenoweth, could only state that digital is priority for the company's strategies and businesses (Chenoweth, 2011).

\section{Conclusion}

For two decades New Zealand's media landscape has been effectively colonised by global and pan-regional media conglomerates. This reflects a broader process whereby the domestic economy has been absorbed into the flows and the networks of global capitalism. As a result, two significant trends have been identified in the ownership and management of New Zealand media institutions.

Firstly, the four overseas players SkyTV, Fairfax Media, APN and MediaWorks are no longer simply stand-alone media conglomerates with shareholder obligations. They must also respond to the high rates of return set by commercial banks, investment banks and private equity companies. For Fairfax, APN and MediaWorks, these commercial pressures are especially acute, although SkyTV's major shareholder NewsCorp has more financial independence. Such developments have led to the closure of a 20 -year-old weekly business paper, job losses for journalists, printers, advertising and distribution workers and government loans for a conglomerate with major broadcast holdings (MediaWorks). Secondly, with APN's and Fairfax's withdrawal from New Zealand Press Association (NZPA), and the governments funding cut for the state-owned digital TV channel TVNZ7, public media space is shrinking as commercial influence expands. 


\section{References}

Abandonment of public service TV 'tragic' for New Zealand. (2011, April 7). The Newswire. Retrieved on 7 April 2011, from www.guide2.co.nz/money/news/business/abandonment-of-public-service-tv-039tragic039-for-new-zealand/11/21513 Ahmed, N. (2011, May 30). Fairfax Media's radio assets attract interest. The Australian. Retrieved on 30 May 2011, from www.theaustralian.com.au/business/ opinion/fairfax-medias-radio-assets-attract-interest/story-fn7rgef9-1226065157714 APN. (2011a, n.d.). Major shareholders. Retrieved on 30 May 2011, from http://phx. corporate-ir.net/phoenix.zhtml?c=144006\&p=irol-ownershipSummary

APN (2011b, n.d.) New Zealand Publishing. Retrieved on 30 May 2011, from www. apn.com.au/newzealand.html

APN (2011c, February 14). APN Starts the year on Several High Notes. [Press Release] Retrieved on 7 April 2011, from www.scoop.co.nz/stories/BU1102/ S00297/apn-starts-the-year-on-several-high-notes.htm

APN, Fairfax warn of lower profits. (2011, May 3). The BusinessDesk. Retrieved on 3 May 2011, from

www.scoop.co.nz/stories/BU1105/S00080/apn-fairfax-warn-of-lower-profits.htm

APN to restructure as earnings slashed. (2011, May 4). The Australian. Retrieved on 4 May 2011, from www.theaustralian.com.au/business/apn-to-restructure-asearnings-slashed/story-e6frg8zx-1226049448331

BBC World Service. (2007). World divided on press freedom. Poll 10 December 2007. Retrieved on 14 April, 2011 from www.globescan.com/news_archives/bbc75/

Bond, G. \& Nippert, M. (2011, June 16). Shock resignation of MediaWorks chief. Retrieved on 16 June 2011, from www.nbr.co.nz/article/shock-resignationmediaworks-chief-mn-p-95390

Cheng, D. (2011, April 7). Axe falls on last public service channel. The New Zealand Herald. Retrieved on 7 April 2011, from www.nzherald.co.nz/nz/news/article. cfm?c id=1\&objectid=10717622

Chenoweth, B. (2011, May 3). A presentation at the APN 2011 Annual General Meeting. Retrieved from http://member.afraccess.com/media?id=CMN://4A231 651\&filename $=20110503 /$ APN_01177094.pdf

Chessell, J. (2011, May 12). Fairfax confirms 82 sub-editors' jobs to go. The Australian. Retrieved from www.theaustralian.com.au/business/media/fairfaxconfirms-82-sub-editors-jobs-to-go/story-e6frg996-1226054570632

Chessell, J., Ahmed, N. (2011, April 25). Fairfax, APN in talks to merge printing. The Australian. www.theaustralian.com.au/business/fairfax-apn-in-talks-to-mergeprinting/story-e6frg8zx-1226044198580

Coleman, J. (2011, May 3). Hansard debates. Television New Zealand Amendment BillSecond Reading. New Zealand Parliamentary Debates. [Volume:672;Page:18270]. Retrieved from www.parliament.nz/en-NZ/PB/Debates/Debates/7/f/b/49Han sD_20110503_00000831-Television-New-Zealand-Amendment-Bill-Second. htmm

Doyle, G. (2002). The economics and politics of convergence and concentration in the UK and European media. (1st ed.) London: Sage Publications. 
Drinnan, J. (2011a, May 6). Secret-squirrel deals becoming norm. The Business Herald. p. 7

Drinnan, J. (2011b, May 4). Advert drop hits APN and Fairfax earnings. The New Zealand Herald. Retrieved from www.nzherald.co.nz/business/news/article. cfm?c_id=3\&objectid=10723221

Drinnan, J. (2011c, April 21). MediaWorks lifeline has strings attached, documents reveal. The New Zealand Herald. Retrieved from www.nzherald.co.nz/newzealand/news/article.cfm?1_id=71\&objectid=10720648

Dwyer. T. (2010). Media convergence. Issues in cultural and media studies. Berkshire: Open University Press.

Fairfax (2010, June 9). Best in the business at business. [Press Release]. Retrieved from www.scoop.co.nz/stories/BU1006/S00229.htm

Fairfax (2011, February 14). 85\%+ of New Zealanders reached by Fairfax Media Brands. [Press Release] Retrieved from www.fairfaxmedia.co.nz/news/article. dot?id $=24013$ \& currentPage $=2$

Fairfax (2011b, May 3). Fairfax Media Limited Trading and Strategic Plan Update. [Trading Update]. Retrieved from www.fxj.com.au/shareholders/StrategicPlanupdate030511.pdf

Fairfax appoints NZ news head. (2011, May 13). Stuff website. Retrieved from www.stuff.co.nz/business/industries/4999760/Fairfax-appoints-NZ-news-head

Fairfax kills NZPA. (2011, April 7) Kiwiblog. Retrieved from www.kiwiblog. co.nz/2011/04/fairfax_kills_nzpa.html

Fairfax to sell radio stations (2011, May 17). The Skynews.com.au. Retrieved from www.skynews.com.au/businessnews/article.aspx?id=613899\&vId=

Govt lends MediaWorks $\$ 43 \mathrm{~m}$ against advice (2011, April 7.) ONE News. Retrieved from http://tvnz.co.nz/politics-news/govt-lends-mediaworks-43m-againstadvice-4108249

INM can't find buyer for its APN stake. (2009, January 27). The ninemsn.com.au. Retrieved from http://news.ninemsn.com.au/business/733404/inm-cant-findbuyer-for-its-apn-stake

Irondbridge (2009, December 18). MediaWorks completes recapitalisation. [Press Release]. Retrieved from www.ironbridge.com.au/press/mediaworks 181209.ht

Jackson, S., Sinclair, L. (2011, May 16). Job cuts rumoured as News eyes Fairfax print deal. The Australian. Retrieved from http://theaustralian.newspaperdirect. com/epaper/viewer.aspx

Joyce, S. (2011, March 9). Order paper and questions: Questions for oral answer. New Zealand Parliamentary Debates, 670. Retrieved from www.parliament.nz/ en-NZ/PB/Business/QOA/9/1/f/49HansQ_20110309_00000012-12-MediaWorksPayment-Arrangement.htm

Keall, C. (2011, March 4). TVNZ7's demise will be Sky TV shareholders' gainanalyst. National Business Review. Retrieved from www.nbr.co.nz/article/tvnz7sdemise-will-be-sky-tv-shareholders-gain-analyst-ck-87497 
Kedgley, S. (2011a, March 9). The government's generosity to private broadcasters. The Frogblog. Blog posted to http://blog.greens.org.nz/2011/03/09/the-governments-generosity-to-private-broadcasters/

Kedgley, S. (2011b, May 5). Shocking TVNZ Amendment Bill. [Speech.]. Retrieved from www.greens.org.nz/speeches/shocking-tvnz-amendment-bill

Keown, J. (2011, April 13). MediaWorks payment went against Treasury advice. National Business Review. Retrieved from www.stuff.co.nz/business/industries/4879571/MediaWorks-payment-went-against-Treasury-advice

Key, J. (2011, March 28 ). Order paper and question: Questions for written answer. New Zealand Parliamentary Debates, 2043. Retrieved from www.parliament. nz/en-NZ/PB/Business/QWA/7/e/e/QWA_02043_2011-2043-2011-Hon-TrevorMallard-to-the-Prime-Minister.htm

Lee, J., Kruger, C. (2010, December 8). Rinehart takes \$50m stake in Fairfax. The Sydney Morning Herald. Retrieved from www.smh.com.au/business/media-andmarketing/rinehart-takes-50m-stake-in-fairfax-20101207-18of6.html

Mallard, T. (2011, March 9). Government still has questions to answer on MediaWorks sweetheart deal. Blog posted to www.labour.org.nz/node/3304

Media giant says it wanted to save NZPA. (2011, April 8). Radio New Zealand. Retrieved from www.radionz.co.nz/news/national/72294/media-giant-says-itwanted-to-save-nzpa

MediaWorks. (2011a). About MediaWorks NZ. Retrieved from www.mediaworks. co.nz/Default.aspx?tabid=38

MediaWorks. (2011b, March 10). Statement on a misleading NZ Herald article Re MediaWorks. [Press Release] Retrieved from www.scoop.co.nz/stories/ BU1103/S00319/statement-on-a-misleading-nz-herald-article-re-mediaworks.htm

MediaWorks whacked with $11.2 \%$ interest on deferred payments to govt. (2011, March 9). National Business Review. Retrieved from www.nbr.co.nz/article/nogovt-loan-media-company-joyce-nn-87815

News agency under review. (2011, April 6). Stuff. Retrieved from www.stuff.co.nz/ timaru-herald/business/4855584/News-agency-under-review

Newspaper ad revenue falls to lowest level in 27 years. (2011, March 6). The Huffington Post. Retrieved from www.huffingtonpost.com/2011/06/03/newspaperad-revenue-fall_0_n_870753.html

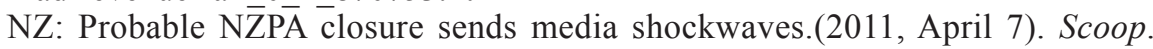
Retrieved from www.pmc.aut.ac.nz/pacific-media-watch/2011-04-07/nz-probablenzpa-closure-sends-media-shockwaves

O'Carroll, L. (2011, June 6). Independent News \& Media in turmoil as O'Reilly and O'Brien continue row. The Guardian. Retrieved from www.guardian.co.uk/business/ireland-business-blog-with-lisa-ocarroll/2011/jun/06/ireland-gavin-o-reilly

Open letter on NZ public broadcasting policy. (2011, April 14). [PDF]. Retrieved from www.pmc.aut.ac.nz/sites/default/files/file_bin/201104/Open\%20Letter\%20 on $\% 20$ Public $\% 20$ Broadcasting\%20April\%202011.pdf 
Plunkett, J. (2011, January 12). BBC Trust chair: we may cut back digital channels. The Guardian. Retrieved from www.guardian.co.uk/media/2011/jan/12/bbc-cutsbbc3-bbc4

Prime Minister defends loan to MediaWorks. (2011, April 8). ONE News. Retrieved from http://tvnz.co.nz/national-news/prime-minister-defends-loan-mediaworks-4109116

Probable closure of NZPA sends shockwaves through media. (2011, April 6). Scoop. Retrieved from www.scoop.co.nz/stories/HL1104/S00045/probable-closure-ofnzpa-sends-shockwaves-through-media.htm

Rosenberg, B. (2008). News media ownership in New Zealand. CAFCA publications. [Electronic version].

Rosenberg, B. (2009). NZ media 2008. Politics and the financial crisis. Pacific Journalism Review 15(1), p. 186-218.

Sky TV NZ.(2011a). Shareholders. Retrieved from www.skytv.co.nz/Default. aspx?tabid $=157 \&$ art id $=2200$

Sky TV NZ (2011b, March 1). TVNZ to Launch 24 Hour Kidzone Channel on Sky. [Press Release]. Retrieved from www.skytv.co.nz/Default.aspx?tabid=202\&art_ id $=35083$

Split down the middle at INM. (2011, June 5). The Sunday Business Post Online. Retrieved from www.sbpost.ie/news/ireland/split-down-the-middle-at-inm-56714.html

Telecom New Zealand (2011, April 15). Telecom and Yahoo!7 confirm change of partnership [Press release]. Retrieved from www.telecom-media.co.nz/releases_detail. asp $? \mathrm{id}=3764$ \&page $=1$ \&pagesize $=10$

Thompson, P. (2011, March 27). Govt shows double standards over broad casting. The Dominion Post. Retrieved from www.stuff.co.nz/dominion-post/comment/4807990/Govt-shows-double-standards-over-broadcast

TVNZ (2011, March 13). TVNZ launches new channel U - Where Facebook meets TV. [Press Release]. Retrieved from http://tvnz.co.nz/content/4060372

TVNZ7 to close as govt confirms no more funding. (2011, April 6). ONE News. Retrieved from http://tvnz.co.nz/national-news/tvnz7-close-govt-confirms-nomore-funding-4104745

Vaughan, G. (2010, February 12). Goldman takes 13\% MediaWorks stake. Stuff. Retrieved from www.stuff.co.nz/business/3320067/Goldman-takes-13-MediaWorks-stake

Watkins, T. (2011, April 7). TVNZ 7 to get the chop. Stuff. Retrieved from www.stuff. co.nz/national/politics/4856878/TVNZ-7-to-get-the-chop

Winseck D. (2008). The state of media ownership and media markets: Competition or concentration and why should we care? Sociology Compass, 2(1), pp. 34-47.

Winston calls on govt to explain 'bail-out' of MediaWorks, owned by Johnny Foreigner. (2011, March 9). National Business Review. Retrieved from www.nbr. co.nz/article/winston-calls-govt-explain-bail-out-mediaworks-owned-johnnyforeigner-ck-87880 
Merja Myllylahti is manager of the JMAD Media Mapping Project at AUT University. She is also a lecturer and PhD researcher in the AUT School of Communication Studies. Her research interest lies in evolving business models of online news media and especially how new pay and subscription models are used by New Zealand media industry.

Merja.Myllylahti@aut.ac.nz

Dr Wayne Hope is an associate professor in Auckland University of Technology's School of Communication Studies. He is curriculum leader for undergraduate media communication courses and teaches a post graduate course entitled Time, Temporality and Globalisation. His specific areas of research include New Zealand economic, political and media history, public sphere analysis, the political economy of communication, sport-media relationships, globalisation and time. Dr Hope is a long standing member of the International Association of Media Communication Research (IAMCR) and a senior contributor to the Political Economy section.

Wayne.Hope@aut.ac.nz

\section{PACIFIC MEDIA CENTRE}

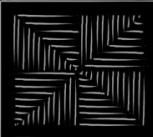

$\overline{\text { PAEIFII }}$ MPE EENTRE TE AMOKURA

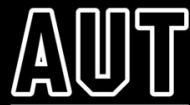

U N I VER S I T Y
The Pacific Media Centre (Te Amokura) is the only media research and community resource centre of its kind in Aotearoa/New Zealand and has a strategic focus on Màori, Pasifika and diversity media and community development:It was established by AUT University's Faculty of Design and Creative Technologies in 2007. having evolved from a cluster of research and community collaborations within the School of Communication Studies.

PMC activities include:

- International book and research publication

- Publication of the peer-reviewed Pacific Journalism Reviewresearch journal

- Publication of Pacific Media Centre Online as a media resource and postgraduate outlet

- Publication of Pacific Media Watch, a regional media monitoring service

- Journalism and media research opportunities

- Asia-Pacific internships for postgraduate students

www.pmc.aut.ac.nz | pmc回aut.ac.nz 